Original research article

\title{
Combination of the role-playing method and video training in undergraduate nursing studies
}

\author{
Šárka Tomová ${ }^{1}$, Mária Kilíková ${ }^{2}$, Daniela Bartoníčková ${ }^{1}$, Dominika Kalánková ${ }^{3}$ * \\ ${ }^{1}$ Charles University in Prague, 2nd Faculty of Medicine, Department of Nursing, Prague, Czech Republic \\ ${ }^{2}$ St. Elisabeth University of Health Care and Social Work in Bratislava, Bratislava, Slovak Republic \\ ${ }^{3}$ Comenius University in Bratislava, Jessenius Faculty of Medicine in Martin, Department of Nursing, Martin, Slovak Republic
}

\begin{abstract}
Objective: The paper aimed to present the results of an innovative strategy that combined role-playing and video training as an effective approach for teaching active listening skills in nursing training.

Design: A descriptive cross-sectional study.

Methods: The data collection was carried out by the standardised observation of the outcomes of how 58 Bachelor's degree nursing program students communicate in model situations. The record sheet was aimed at monitoring the skills of active listening and its verbal and nonverbal expressions. The data were analysed by quantitative and qualitative analysis.

Results: The results indicate improvement in active listening skills after completing the training - in both verbal and non-verbal communication.

Conclusions: By combining the role-playing method with video training and increasing the frequency of sessions, communication skills are improved, and therefore, the quality of nursing care may also be improved.
\end{abstract}

Keywords: Active listening; Role-play; Simulation; Video training

\section{Introduction}

Effective and useful communication is one of the essential elements of nursing, and a critical aspect in the provision of high-quality health care to patients (Furnes et al., 2018).

Communication is particularly vital for nurses as they provide daily and ongoing care to patients, and as such it is included among the core competencies of nursing standards across the globe (Gabrielsen et al., 2016; Wang et al., 2015). Nurses with excellent communication skills are very important for patients. These skills are included among the core competencies of a nurse, not only in our country but also at an international level. Communications skills are crucial for patient safety, the nurse-patient relationship and effective patient care (Szpak and Kameg, 2013). Therefore communications skills are an integral part of undergraduate nursing programs (Choi et al., 2014). While the ability to communicate can be learned, the healthcare professional must continue to professionally develop this skill (Bártlová et al., 2010). The impact of nursing communication skills training and its positive effect on their development has been documented in several newer studies (e.g., MacLean et al., 2019; Omura et al., 2019; Wittenberg et al., 2019). Thanks to the teaching of communication skills, students of nursing are then able to apply these skills when communicating with patients in practice. Successful training in communication skills leads to an increase in students' knowledge and attitudes, and depends primarily on the management of training courses (Katebi et al., 2015). However, in today's training, real training is required rather than traditionally used theoretical lectures. For the sake of improvement, new technologies are therefore being used, bringing together a variety of tools, forms, methods, and resources that can be used in teaching (Bristol and Zerwekh, 2011).

These training methods may include, for example, real-life lessons, patient education training, as well as teaching methods such as role-playing and video training as feedback. Innovative methods of communication simulation are defined as educational methods that create a clinical experience through interactive activity in a safe learning environment without fear of personal failure or harm to patients' health (McCaughey and Traynor, 2010). These artificially induced states of communication provide new opportunities in preparation for meeting real-world patients and are also an appropriate method for achieving overall improvement in communication skills in nursing practice (Furnes et al., 2018).

One of the effective methods mentioned is the role-playing method, which is accessible and serves to develop the fundamental component of the evolution of communication skills. It emphasises the development of the senses and the

\footnotetext{
* Author for correspondence: Dominika Kalánková, Comenius University in Bratislava, Jessenius Faculty of Medicine in Martin, Department of Nursing, Malá Hora 5, 03601 Martin, Slovak Republic; e-mail: kalankova1@uniba.sk http://doi.org/10.32725/kont.2020.002

Submitted: 2019-10-24 • Accepted: 2020-01-16 • Prepublished online: 2020-01-30 
emotional involvement of students in the field of communication (Katebi et al., 2015). Activating the role-playing method in practical training automatically leads to the acquisition of active listening skills. The ability to listen is considered to be one of the necessary preconditions for professional nursing behaviour (Kluge and Glick, 2006). Applying this method to teaching communication enables students to practice communication skills, and for overall improvement, they can also provide feedback through videotape, as is evident in the results of many studies (Aebersold and Tschannen, 2013; Fisher and King, 2013; Oh et al., 2015; Shin et al., 2015).

One of the supporting methods that is considered as one of the most effective ways of developing communication is video training. It allows students to follow their conversation and interactive techniques, which in particular enhances their performance and personal development. Through the self-image of the recording, this also helps to improve non-verbal behaviour, as well as verbal expression techniques, including paraphrasing and interpretation (Choi et al., 2014; Katebi et al., 2015).

Because of the benefits of both methods - role-playing and video training - it is adequate to use them together in a simulated lab exercise for teaching communication in undergraduate nursing studies. This paper aims to interpret an innovative strategy to improve selected communication skills, namely active listening on verbal and nonverbal expressions, combining the role-playing and video training methods for students of the undergraduate nursing studies program.

\section{Material and methods}

This paper presents the findings from a descriptive cross-sectional study. The research was approved by the institutional board committee (EK-334/19). The study was conducted between the years 2016 and 2019.

\section{Sample characteristics}

The research sample consisted of students of the 2nd year of the Bachelor study program 'General Nurse and General Nurse with Extended Teaching in Pediatric Nursing' between 20162019 within a single medical faculty in the Czech Republic. All of the students had completed the training of Communication in Nursing. The recruitment of the students was carried out by the teacher who led the training. Each respondent was thoroughly informed about the research objectives and their progress. Students were included in the research sample, and their informed written consent was required. Before the research, researchers were asked for verbal consent. In the academic year 2016/17, the sample group consisted of 16 students, in the following academic year of 2017/18 the group consisted of 18 students, and in the academic year 2018/19 24 students of the earlier mentioned fields were part of the sample group. The intervention group was formed by a total of 58 respondents.

\section{Data collection and data analysis}

In the context of the research, the monitoring of communication skills was conducted through structured observation of active listening skills and subjective evaluation of students by focus group discussions. The method of structured observation was done by standardised evaluation in connection with the pre-prepared sheet of categorical systems. The particular items were included in the sheet based on the literature review. These items must be related to the communication skill of active listening. The final items were evaluated by six ex- perts who used the Likert scale ( 1 - not relevant, 4 - very relevant) to mark the relevancy of these items. The CVI index was 0.80 . The observational sheet included two basic categories of verbal (I/A) and nonverbal (I/B) active listening.

The perception of active listening skill was marked by a selected number on the Likert scale $1-5$, with the number 1 representing totally unsatisfactory and 5 representing totally satisfactory. Within the objectivity of observation, the assessment was evaluated by the pedagogue (SP1) and psychologist (SP2) twice - before and after teaching the students the active listening skills in their communication training. As a part of the assessment, students were asked to use the role-playing method to cope with the active listening skill of nurses. In the beginning, there was an initial seminar in which the role-playing teaching methods were explained - before the students commenced their communication training. Also, to make the performances of students' objective, accurate and reliable, the monitored categories were previously introduced them. The classroom scene for observer training took place in a model vocational classroom that perfectly imitated the hospital clinical environment and was still the same for students' outputs. The patients' role was played by students of the general nurse bachelor's degree program, according to a predefined scenario, and after a detailed briefing that focused on role-plays. The thematic basis for creating the scenario situation was communication between a nurse and a patient. Students chose one of the themes to process a 10-15-minute output by random selection. The time for preparation and the processing of the information concerning this topic was one week. During this preparation, the student could consult his/her approach with the pedagogue. After the preparation phase, the initial assessment of the execution was conducted by the specialists (before the start of the communications training - PRE) who recorded the assessment into the categorical sheet. Students then attended training in the communication skill of active listening. Video training was used as an innovative method during the half-year training. Approximately half way through the course, students were asked to present the model situation using the role-playing method in the same way as at the beginning. The model situation was recorded on the video.

Subsequent analysis of video recordings of a student's own outputs was, according to the student's wishes, performed either in front of the group or individually with the pedagogue. This analysis was completed before the final evaluation of the progress in the communication skill of active listening. After the end of this training (POST), the pedagogue (SP1) and psychologist (SP2) evaluated the performance of students using the role-playing method by recording this performance in the observational sheet, which was the same as at the beginning. Processed communication situations were again different. By using a video in training, it was observed whether there was a shift in active listening.

After the end of the thematic part with the use of video recordings and after the structured observation, the training of communication ended with a seminar during which, through a controlled interview with the students, the benefit was assessed qualitatively. Also, during this seminar, the result of the shift in active listening skills was presented to the students. All statistical calculations were performed in the StatSoft Statistica software. Statistic tests were performed at a significance level of $\alpha=0.05$. Statistical analysis of the acquired data was used to compare the differences between the average level of active listening skills of students, and was measured by the structured observation of specialists before and after passing the communication training. The benefits of the combination 
of role-playing method and video training were emphasised by qualitative statements of students which resulted from the discussions after the final evaluation of the subject.

\section{Results}

\section{Results from quantitative analysis}

The analysis of variance revealed significant differences both in verbal and non-verbal expressions of undergraduate students - between the level of active listening skills before and after the parallel use of the role-playing and video training method. A graphical representation of the difference in the average level of communication skills I/A for pre and post, which included six verbal, active listening exercises: encouraging, clarifying, mirroring, paraphrasing and summarising, is illustrated in Chart 1. After finishing the video outputs in combination with the role-playing method, the category of active listening and non-verbal analysis showed a significant increase in the IA category, $p<0.00001$.

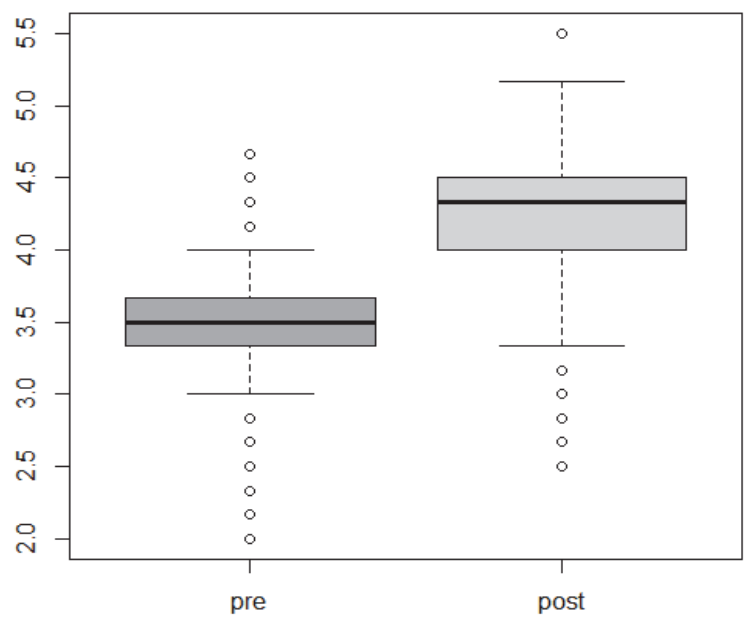

${ }^{*}$ Numbers in the diagram represent the average values of
communication skills.

Chart 1. The difference in communication skills of active I/A listening (verbal expressions) before and after completion of the video training in combination with the role-playing method in students of the undergraduate nursing study program.

A graphical representation of the difference in the average level of communication skills I/B for pre and post, which included six items of active nonverbal listening: maintaining the view, attitude, gesticulation, mimics, movements and distance, is shown in Chart 2. After finishing the video outputs in combination with the role-playing method, the category of active listening and non-verbal analysis showed a significant increase in the IB category, $p<0.00001$.

A graphical representation of the difference in the average level of communication skills I and I/I and I/B for pre and post that included verbal and nonverbal expressions of active listening is shown in Chart 3. After finishing the video outputs in combination with the role-playing method, the category of active listening and non-verbal analysis showed a significant increase in the average of the I category, $p<0.00001$.

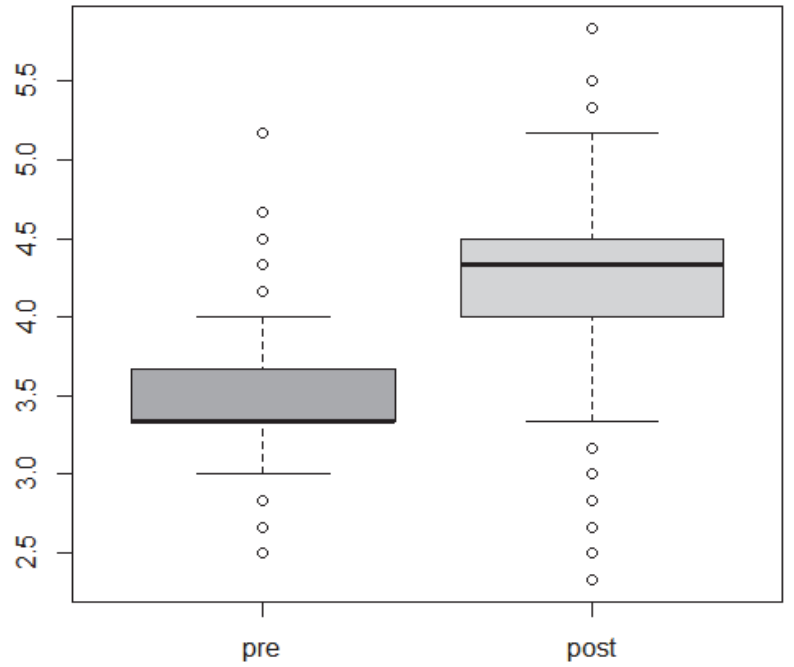

* Numbers in the diagram represent the average values of communication skills.

Chart 2. The difference in communication skills of active I/B listening (non-verbal expressions) before and after completion of the video training in combination with the role-playing method in students of the undergraduate nursing study program.

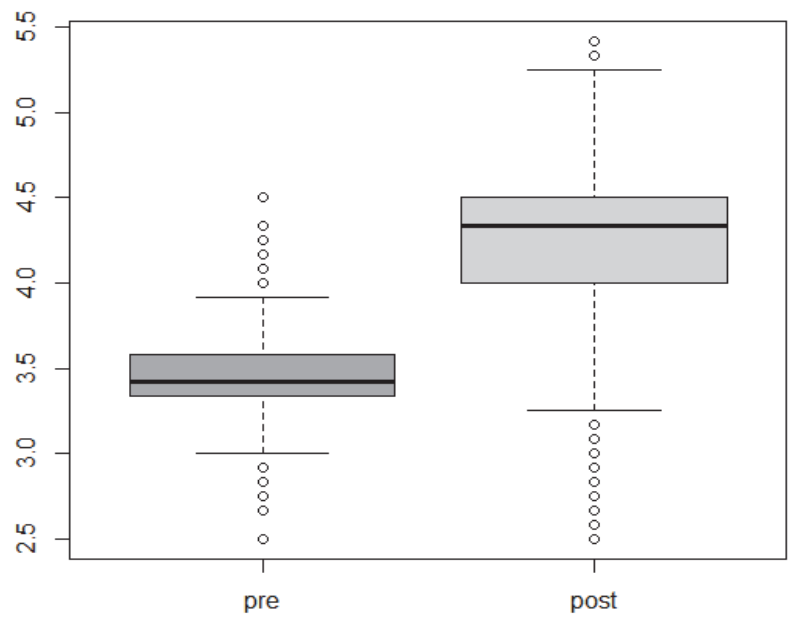

${ }^{*}$ Numbers in the diagram represent the average values of communication skills.

Chart 3. The difference in communication skills of active I listening (verbal \& non-verbal expressions) before and after completion of the video training in combination with the role-playing method in students of the undergraduate nursing study program.

\section{Results from the qualitative analysis of students' statements}

After the completion of the course, specialists asked students to describe their perception about combining the role-playing method and video training in teaching active listening skills. In the academic year 2016/2017, 14 of 16 students confirmed the benefits of the combination of these methods. In the academic year 2017/2018, all 18 students recommended the combination of role-playing method and video training, and in the last evaluated academic year 2018/2019, 21 of 24 students emphasised the benefits of methods in teaching an active listening skill. 
According to the extent of this paper, we reported only a few statements that highlight students' perception of combining the role-playing method and video training in the teaching of active listening skills.

Some of the students presented benefits that related to their confidence, e.g. "I am much more confident in my verbal expression."

"I liked the way I could compare my opinion with the opinions of other students."

"I got rid of my shyness..."

In addition, students were much more aware of their own communication skills.

"This innovative training was better than two years of learning the theory."

"... moreover, I found out how difficult it is to focus on my non-verbal expression while speaking meaningfully."

"I have also tried things I can use in my personal life."

Furthermore, the majority of students positively evaluated video training as an activating teaching method. The initial shyness due to the presence of video camera, as well as the particpants' fear of criticism, represented a stressful situation for students. Their own decision to record an authentic communication situation helped students to overcome a barrier that many of them had considered insurmountable. This is expressed in some of the students' statements:

"I was worried that I would not able to answer all of the patients' questions."

"I was afraid of what others would say."

"It made me nervous at that time, but now I feel more confident."

"It was scary to see myself in the video, but I could have seen the mistakes when communicating with the patient."

The majority of respondents stated that the concerns arising from the fear of shooting the video were not justified. According to their statements, it was necessary to focus on the content of the simulated situation and completely "immerse" themselves in conversation with the patient. Students evaluated the benefit of video recording and its analysis as a very effective method that can be used in preparation for communication with the patient in a real clinical placement - even though they realise that only clinical practice will give them the required experience. The students described several main benefits. One of them was the possibility to return to the problematic issues of the interview with the patient at any time and the reflection of their own non-verbal reactions related to the patient. Another one was to evaluate the quality and adequacy of the expression as well as other non-verbal signals of the body. The final benefit described by students was helping them to cope with the stress, fear and worries that come with public performance.

\section{Discussion}

This study aimed to demonstrate an improvement in the communication skill of active listening in students of undergraduate nursing training after completing their training in communication. With the help of a combination of role-playing and video training methods, improvement in the field of active listening has been identified - in both verbal and non-verbal expressions. Applying a combination of different concepts in teaching not only improves psychomotor skills but also knowledge and other cognitive abilities (Fisher and King, 2013; Norman, 2012; Oh et al., 2015; Shin et al., 2015). Moreover, Fisher and King (2013) demonstrate that their synthesis with the role simulation/role-playing method allows the integration of knowledge into practice, which was also confirmed by Weaver (2011).

It has been shown that training of clinical situations, diagnostic and therapeutic procedures before a real encounter with a patient is the basis for the development of psychomotor skills (Shin et al., 2015). Simulation and role-playing methods are referred to as effective instructional methods aimed at improving communication skills (MacLean et al., 2019; Omura et al., 2019). Using real people in these methods empowers students in self-reflection and self-confidence, increasing their confidence and motivation (Fisher and King, 2013; Norman, 2012; Oh et al., 2015; Shin et al., 2015). It is also important to simulate the situation in a realistic but secure environment (Fisher and King, 2013). Also important is the principle of individual pace (Benner et al., 2010), which was also used in our research. In the search for similar studies, few studies have been found combining the role-playing and video training methods in improving communication skills among nursing students (e.g., Wang et al., 2015).

In the context of focusing our research on active listening, no similar study was found. It has been shown that the combination of role-playing and video training in pre-university nursing students improves the perception of their communication skills (Wang et al., 2015). Using the role-playing method during communication training not only positively affects communication skills, but also the emotional intelligence of individuals (Park, 2013). The role-playing method is primarily used to train a student when experiencing new situations for the first time. It helps to develop communication professionalism by raising students' awareness of their communication level, developing their empathy and also giving them an insight into frequently neglected elements of communication during conversations with patients (Baile and Blatner, 2014). Studies show that role-playing is more effective in nursing training than illustrative methods (Sato et al., 2017) or lectures (Chaharsoughi et al., 2014).

Therefore, during the teaching of communication skills active listening was applied in our research. Video training based on specialists' assessment is a beneficial instructional method that helps university students develop an awareness of their strengths and weaknesses in communication. It is an alternative method of teaching to increase communication skills in practice (Lai, 2016; Yoo et al., 2009). It allows students to experience a dialogical reflection in which they represent themselves or another person (Vizeshfar et al., 2019). Every situation that is captured on video contains lots of data. It is demonstrable that the use of the video is useful when the student is informed in advance of what evaluation parameters he/she should focus his/her attention on. Another advantage is the possibility of unfolding a discussion about the observed aspect. The research findings on the impact of video and its effectiveness in teaching agree that videoing "someone else" appears to be more appropriate for observing model behaviour, while videoing "oneself" seems more suitable for reflective learning, and it is the basis for changing or extending models of negotiation. The results of our research confirm this fact (Nusbaum et al., 2019).

\section{Conclusion}

In the framework of the research, we introduced an innovative strategy to improve the communication skills of active listening by linking role-playing and video training methods for 
students of the undergraduate nursing study program. It has been shown that the improvement of communication skills occurred both in verbal and non-verbal expressions of students. Nowadays, different teaching methods are used to teach students, but for now, no method has been proven to be the best. We believe in the benefits of our method. This way of teaching communication skills involving active listening can also be a significant source for revealing strengths and weaknesses in the field of communication - which can then further influence the behaviours of different individuals in clinical practice. Acquiring these communication skills that involve active listening by role-playing and analysing video footage can be a way to get rid of a students' uncertainty, fear and fear of direct contact with a patient.

The chosen method confirms its efficiency and excellence, primarily in the field of the self-concept and self-reflection of a student. It helps the student to see himself, his reactions, the quality of his vocabulary, but above all, to read his non-verbal expression in a situation where he focuses on the patient and his current state. It is not easy to handle all the skills immediately. It requires training accompanied by feedback that shows both the progress and the areas that need to be addressed. Acquiring these discussed communication skills through active listening, quality training, and increased frequency of use will allow each nurse to practice consistently with emphasis on their individualisation in terms of access to the patients, thus promoting the profession of nurse as a kind of art, which will also possibly further contribute to the improvement of nursing care in general. In line with the evolution of IT technologies, virtual reality or other innovative methods could be used in future in connection with this topic.

\section{Limitations of the research and implications for practice}

Using video training combined with role-playing methods for acquiring communication skills is a time-consuming process. Preparing model situations, explaining the effects of the video footprint to participants, time synchronisation of the camera operator following the days on which the video is shot, and the requirement to record both individual and total shots made requires careful, tedious, time-consuming and time-consuming preparation. Another limitation of the research may be the small number of participants of the study taken. However, due to the demanding nature of the method, it is not possible to apply this method to a larger number of students. If the use is meaningful and beneficial, it is not only necessary to devote time to the output recorded on camera, but also to the process of the recording. As a result, students can learn from their own mistakes more quickly.

Another limitation of our study was the lack of current literature, but this is also what makes our research so important. The design of our research is also one of the limitations. There is a need to use the experimental design with a control group of students in further studies. Another limitation of the research to consider is the fact that role-playing methods combined with video training can also be used for other communication skills, not just active listening. However, if we assess several skills at the same time, the student may lose the ability to focus on the particular skill selected or to observe it according to the stated requirements. It is, therefore, necessary to carry out more research in this field.

\section{Conflict of interests}

The authors have no conflict of interests to declare.

\section{Ethical considerations}

The study was approved by the Ethics Committee of the University Hospital Motol and 2nd Faculty of Medicine, Charles University in Prague (EK-334/19).

\section{Acknowledgements}

This research did not receive any specific grant from funding agencies in the public, commercial, or not-for-profit sectors.

\section{Kombinace metody hraní rolí a videotréninku v pregraduální připravě sester}

\section{Souhrn}

Cíl: Cílem příspěvku je předložit výsledky inovativní strategie, a to kombinace výukové metody hraní rolí a videotréninku jako účinného nástroje $\mathrm{k}$ osvojování dovednosti aktivního naslouchání v pregraduální přípravě sester.

Design: Popisná průřezová studie.

Metodika: Sběr dat byl proveden technikou standardizovaného pozorování komunikačních výstupů 58 studentů bakalářského studijního programu ošetřovatelství v modelových situacích. Záznamový arch byl zaměřen na sledování dovednosti aktivního naslouchání a jejích verbálních a neverbálních projevů. Data byla zpracována prostřednictvím kvantitativní a kvalitativní analýzy. Výsledky: Výsledky potvrzují posun v osvojení si dovednosti aktivního naslouchání po absolvování výuky komunikace, a to jak v části verbální, tak i neverbální.

Závěr: Kombinací metody hraní rolí s videotréninkem a navýšením frekvence jejího použití se vybrané komunikační dovednosti zlepšují a z toho důvodu může docházet i ke zkvalitňování ošetřovatelské péče celkově.

Klíčová slova: aktivní naslouchání; hraní rolí; simulace; videotrénink

\section{References}

1. Aebersold M, Tschannen D (2013). Simulation in Nursing Practice: The Impact on Patient Care. Online J Issues Nurs 18(2): 6. DOI: 10.3912/OJIN.Vol18No02Man06.

2. Baile WF, Blatner A (2014). Teaching communication skills: using action methods to enhance role-play in problem- based learning. Simul Healthc 9(4): 220-227. DOI: 10.1097/ SIH.0000000000000019.

3. Bártlová S, Chloubová I, Trešlová M (2010). Vztah lékař sestra. Brno: NCO NZO.

4. Benner P, Suthpen M, Leonard V, Day L (2010). Educating nurses: a call for radical transformation. San Francisco: JosseyBass.

5. Bristol TJ, Zerwekh J (2011). Essentials of e-learning for nurse educators. Philadelphia: Davis Company. 
6. Chaharsoughi NT, Ahrari S, Alikhah S (2014). Comparison the effect of teaching of SBAR technique with role play and lecturing on communication skill of nurses. J Caring Sci 3(2): 141-147. DOI: $10.5681 /$ jcs.2014.015.

7. Choi Y, Song E, Oh E (2014). Effects of teaching communication skills using a video clip on a smart phone on communication competence and emotional intelligence in nursing students. Arch Psychiatr Nurs 29(2): 90-95. DOI: 10.1016/j. apnu.2014.11.003.

8. Fisher D, King L (2013). An integrative literature review on preparing nursing students through simulation to recognize and respond to the deteriorating patient. J Adv Nurs 69(11): 2375-2388. DOI: 10.1111/jan.12174.

9. Furnes M, Kvaal KS, Høye S (2018). Communication in mental health nursing - Bachelor Students' appraisal of a blended learning training programme - an exploratory study. BMC Nursing 17: 20. DOI: 10.1186/s12912-018-0288-9.

10. Gabrielsen AK, Karlsen MMW, Falch AL, Stubberud DG (2016). Communication training course with simulation. Sykepleien 2016(11): 184-192. DOI: 10.4220/Sykepleienf.2016.57832.

11. Katebi MS, Khadivzadeh T, Shamloo ZS, Esmaeili H (2015). Comparison of the effects of role play and video feedback on the knowledge and attitude of midwives towards communication skills training. J Nurs Mid Sci 2(3): 1-9. DOI: 10.7508/ jnms.2015.03.001.

12. Kluge MA, Glick L (2006). Teaching therapeutic communication VIA camera clues and clues: the video inter-active (VIA) method. Journal of Nursing Education 45(11): 463-468. DOI: 10.3928/01484834-20061101-07.

13. Lai CY (2016). Training nursing students' communication skills with online video per assessment. Comput Educ 97(2016): 31-30. DOI: 10.1016/j.compedu.2016.02.017.

14. MacLean S, Geddes F, Kelly M, Della P (2019). Realism and presence in simulation: Nursing student perceptions and learning outcomes. J Nurs Educ 58(6): 330-338. DOI: 10.3928/01484834-20190521-03.

15. McCaughey CS, Traynor MK (2010). The role of simulation in nursing education. Nurse Education Today 30(8): 827-832. DOI: 10.1016/j.nedt.2010.03.005.

16. Norman J (2012). Systematic review of the literature on simulation in nursing education. ABNF J 23(2): 24-28.

17. Nusbaum L, Douglas B, Estrella-Luna N, Paasche-Orlow M, Damus K (2019). Survey of risks and benefits communication strategies by research nurses. Nurs Ethics 26(3): 937-950. DOI: $10.1177 / 0969733017734410$.
18. Oh PJ, Kyeong DJ, Koh MS (2015). The effects of simulationbased learning using standardised patients in nursing students: a meta-analysis. Nurse Educ Today 35(5): e6-e15. DOI: 10.1016/j.nedt.2015.01.019.

19. Omura M, Levett-Jones T, Stone TE (2019). Design and evaluation of an assertiveness communication training programme for nursing students. J Clin Nurs 28(9-10): 1990-1998. DOI: 10.1111/jocn.14813.

20. Park E (2013). Effects of family nursing practicum using role play on emotional intelligence, communication ability, and family nursing performance of nursing students. J Korean Acad Soc Nurs Educ 19(4): 656-662. DOI: 10.5977/ jkasne.2013.19.4.656.

21. Sato Y, Okamoto S, Kayaba K, Nobuhara H, Soeda K (2017). Effectiveness of role-play in hazard prediction training for nursing students: A randomized controlled trial. J Nurs Educ Pract 8(2): 1-7. DOI: 10.5430/jnep.v8n2p1.

22. Shin S, Park JH, Kim JH (2015). Effectiveness of patient simulation in nursing education: a meta-analysis. Nurse Educ Today 35(1): 176-182. DOI: 10.1016/j.nedt.2014.09.009.

23. Szpak JL, Kameg KM (2013). Simulation decreases nursing student anxiety prior to communication with mentally ill patients. Clin Simul Nurs 9(1): e13-e19. DOI: 10.1016/j. ecns.2011.07.003.

24. Vizeshfar F, Zare M, Keshtkaran Z (2019). Role-play versus lecture methods in community health volunteers. Nurse Educ Today 79: 175-179. DOI: 10.1016/j.nedt.2019.05.028.

25. Wang W, Liang Z, Blazeck A, Greene B (2015). Improving Chinese nursing students' communication skills by utilizing video-stimulated recall and role-play case scenarios to introduce them to the SBAR technique. Nurse Educ Today 35(7): 881-887. DOI: 10.1016/j.nedt.2015.02.010.

26. Weaver A (2011). High-fidelity patient simulation in nursing education: an integrative review. Nurs Educ Perspect 32(1): 37-40. DOI: 10.5480/1536-5026-32.1.37.

27. Wittenberg E, Goldsmith J, Buller H, Ragan SL, Ferrell B (2019). Communication training: Needs among onkology nurses across the cancer continuum. Clin J Oncol Nurs 23(1): 82-91. DOI: 10.1188/19.CJON.82-91.

28. Yoo MS, Son YJ, Kim YS, Park JH (2009). Video-based self-assessment: Implementation and evaluation in an undergraduate nursing course. Nurs Educ Today 29(6): 585-590. DOI: 10.1016/j.nedt.2008.12.008. 